\title{
Sanksi Hukum Penerbangan Balon Udara llegal di Kabupaten Wonosobo
}

\author{
Yohanes Aldi Sundoro ${ }^{*}$, Pulung Widhi Hari Hananto² \\ 1Fakultas Hukum, Universitas Negeri Semarang \\ 2Fakultas Hukum, Universitas Diponegoro \\ *aldisundoro31@gmail.com
}

\begin{abstract}
Cases of aircraft accidents that often occur at this time are very public attention, because in addition to the close time intervals and hit almost all airlines, also the most highlighted public attention is the death toll. Public trust in comfort and safety in the use of air transportation is diminishing, even though the need for use is very high. On the other hand, there was an incident where a report on community activities that had the potential to interfere with flight safety was the culture of flying a balloon in Wonosobo Regency. Basically this activity has been happening for years, but in reality this activity has become a polemic between the community and the government. The purpose of this study is to reveal the dangers of using illegal air balloons and sanctions for illegal air balloon pilots. In this study, researchers used a normative juridical method with the type of doctrinal research. The approach taken is conceptual. So the authors in this paper will describe how the dangers of hot air balloon flight in the world of flight and describe how sanctions for air balloon pilots who do not have permission to fly.
\end{abstract}

Keywords: Illegal Air Balloon; Penalty; Community.

\begin{abstract}
ABSTRAK
Kasus kecelakaan pesawat terbang yang sering terjadi saat ini sudah sangat menyita perhatian masyarakat, karena selain interval waktu yang berdekatan dan melanda hampir seluruh maskapai penerbangan, juga yang paling menyorot perhatian publik adalah timbulnya korban jiwa. Kepercayaan masyarakat atas kenyamanan dan keselamatan dalam penggunaan moda transportasi udara tersebut semakin berkurang, meskipun kebutuhan atas penggunaannya sangat tinggi. Di sisi lain, ada suatu peristiwa dimana terjadi laporan mengenai kegiatan masyarakat yang berpotensi mengganggu keselamatan penerbangan yaitu budaya menerbangkan balon udara di Kabupaten Wonosobo. Pada dasarnya kegiatan ini sudah terjadi bertahuntahun, namun pada kenyataannya kegiatan ini menjadi polemik antara masyarakat dengan pemerintah. Tujuan dari penelitian ini adalah untuk mengungkap mengenai bahaya dalam menggunakan balon udara illegal dan sanksi bagi penerbang balon udara illegal. Dalam penelitian ini, peneliti menggunakan metode yuridis normatif dengan tipe penelitian doktrinal. Pendekatan yang dilakukan adalah konseptual. Sehingga penulis dalam penulisan ini akan menguraikan bagaimana bahaya dalam penerbangan balon udara dalam dunia penerbangan dan menguraikan mengenai bagaimana sanksi bagi para penerbang balon udara yang tidak memiliki izin untuk diterbangkan.
\end{abstract}

Kata Kunci: Balon Udara Ilegal; Sanksi; Masyarakat. 
Jurnal Pembangunan Hukum Indonesia

Volume 2, Nomor 2, Tahun 2020

\section{A. PENDAHULUAN}

Di masa sekarang ini, memang tidak dapat dipungkiri bahwa dalam penyelenggaraan kegiatan penerbangan dirasakan semakin strategis dari waktu ke waktu. Selain mendukung kegiatan dan pertumbuhan ekonomi, dalam industri penerbangan juga menjadi stimulus untuk mendukung pengembangan di sektor industri lainnya. Seperti mendorong pertumbuhan industri pariwisata, memantapkan perwujudan wawasan nusantara, serta untuk menghubungkan daerah-daerah terpencil dalam usaha mencapai tujuan pembangunan nasional (Sudiro, 2011). Keberadaan instrumen hukum yang sistematis dan komprehensif dalam penyelenggaraan industri penerbangan yang memadai memang mutlak diperlukan. Hal ini guna untuk menjamin keamanan dan keselamatan penerbangan, sehingga tidak menimbulkan kerugian pada pihak lain.

Seperti pada penyelenggaraan kegiatan pengangkutan yang dilakukan melalui jalur darat, laut dan udara, juga memiliki kelebihan dan kekurangan masing-masing. Pengangkutan lalu lintas dan angkutan jalan dapat mengangkut barang dalam jumlah besar, namun jarak yang bisa ditempuh jangkauannya sangat terbatas. Pengangkutan melalui laut, sungai dan danau dapat mengangkut barang dalam jumlah besar dan jangkauan jarak
Program Studi Magister IImu Hukum Fakultas Hukum Universitas Diponegoro yang ditempuh bisa sampai ke luar negeri. Demikian juga dengan angkutan penerbangan, dapat mengangkut barang sampai ke luar negeri dengan waktu yang lebih cepat, efektivitas waktu pada angkutan udara, membuat pengirim barang lebih memilih jalur angkutan udara, meskipun jumlah barang yang diangkut tidak sebanyak pengangkutan barang melalui jalur laut. Angkutan penerbangan pada saat ini juga sangat diminati oleh penumpang, mengingat biaya angkutan penerbangan domestik saat ini yang tidak terlalu mahal dan dapat dijangkau oleh masyarakat, dan juga didukung oleh banyaknya jumlah maskapai penerbangan milik swasta yang beroperasi untuk melayani kebutuhan masyarakat melakukan angkutan penerbangan (Aflah, \& Chari, 2017).

Terlebih dengan semakin banyaknya perusahaan penerbangan saat ini baik yang dikelola oleh pihak pemerintah atau Badan Usaha Milik Negara (BUMN) maupun pihak swasta dapat menjadi rivalitas dalam industri penerbangan. Besarnya persaingan keras di antara perusahaan penerbangan terutama terjadi dalam tarif penerbangan, pengguna jasa penerbangan yang berpendapatan rendah lebih tertarik pada tarif penerbangan murah, bagi yang berpendapatan tinggi meskipun bersedia membayar tarif mahal, tetap menginginkan mutu pelayanan dan keselamatan yang lebih terjamin (Adisasmita, 2014). 
Jurnal Pembangunan Hukum Indonesia

Volume 2, Nomor 2, Tahun 2020
Program Studi Magister IImu Hukum Fakultas Hukum Universitas Diponegoro
Setiap pengoperasian pesawat udara, baik pesawat udara sipil maupun pesawat udara negara berpotensi untuk menimbulkan resiko apakah bagi pihak operator maupun bagi pihak lain meskipun dewasa ini pesawat udara adalah moda angkutan yang menggunakan teknologi tinggi. Dengan makin tingginya teknologi penerbangan maka kecepatan dan tingkat keselamatan penerbanganpun semakin tinggi pula. Namun demikian, kenyataan membuktikan bahwa kecelakaan yang menimpa dunia penerbangan masih juga terjadi, di samping itu, kerugian-kerugian yang diderita para pengguna jasa angkutan yang diakibatkan oleh sebab-sebab lain masih sering terjadi. Untuk itu, keselamatan, efisiensi, dan keteraturan dalam angkutan udara merupakan hal yang mutlak dipenuhi. Setiap gangguan terhadap angkutan udara akan merugikan, bukan saja para penumpang dan pengirim kargo, melainkan juga akan membahayakan pesawat udara dan penerbangan itu sendiri (Saefullah, 2003).

Jumlah maskapai penerbangan yang semakin hari bertambah ini menyebabkan bertambahnya pula dibukanya jalur atau rute penerbangan ke berbagai daerah di dalam negeri maupun diluar negeri. Pembukaan dan pertambahan jalur-jalur baru penerbangan udara ini menyebabkan lalu lintas udara menjadi padat, sehingga diperlukan suatu pelayanan lalu lintas udara yang baik untuk terciptanya keamanan dan keselamatan dalam dunia penerbangan. Dengan meningkatnya jumlah angkutan penerbangan sipil di Indonesia saat ini, memerlukan suatu pelayanan lalu lintas penerbangan yang dapat memperlancar dan menjaga keteraturan arus lalu lintas penerbangan, memberikan informasi yang berguna untuk keselamatan penerbangan, sehingga dapat mencegah terjadinya kecelakaan pada angkutan penerbangan (Khairandy, 2006).

Seperti hal nya pada penerbangan balon udara di Kabupaten Wonosobo saat ini yang mejadi tradisi rutinan yang dilakukan pada setiap momen Hari Raya ledul Fitri. Masyarakat mengklaim festival balon yang rutin diadakan tersebut merupakan sebuah tradisi yang sudah dilakukan turun-temurun sejak dahulu sebagai momen ajang gengsi dan mencurahkan kreativitas tiap desa dalam pembuatan balon dengan berbagai macam ukuran dan bentuk. Sehingga pada saat Hari Raya ledul Fitri di Kabupaten Wonosobo dapat disaksikan banyak sekali terlihat balon udara yang terbang bebas di atas langit di Wonosobo. Dalam tradisi menerbangkan balon udara ini sangatlah memiliki resiko yang besar, seperti balon tersebut rentan bertubrukan dengan pesawat yang sedang melintas dan juga bisa berakibat serius bila terkena mesin pesawat. Balon juga berbahaya bila terkena kokpit karena menghalangi penglihatan pilot. Ada juga 
Jurnal Pembangunan Hukum Indonesia

Volume 2, Nomor 2, Tahun 2020
Program Studi Magister IImu Hukum Fakultas Hukum Universitas Diponegoro kemungkinan lain dapat menutupi pipa pitot yang akan membuat sistim pesawat menjadi kacau, dan masih banyak akibat berbahaya lainnya.

Pemerintah Kabupaten Wonosobo juga telah mengeluarkan Peraturan Daerah Nomor 2 tahun 2016 tentang Ketertiban dan Ketentraman Masyarakat yang terdapat dalam Pasal 34 ayat (2) menyatakan bahwa, "orang / badan dilarang membuat, menyimpan, memperjual belikan, dan menerbangkan balon udara dan sejenisnya." Adapun dalam penerbangan balon udara tradisional ini juga telah diatur didalam Peraturan Menteri Perhubungan Nomor 48 Tahun 2018 tentang Penggunaan Balon Udara Pada Kegiatan Budaya Masyarakat. Dengan adanya peraturan tersebut maka berjalannya festival balon udara menjadi perdebatan antara masyarakat yang mengklaim itu sebagai tradisi dan pemerintah yang secara tegas melarang penerbangan balon udara di wilayah Kabupaten Wonosobo lantaran dinilai dapat membahayakan penerbangan.

Berdasarkan pada latar belakang yang telah diuraikan diatas, maka sudah didapati bahwa keselarasan mengenai penerbangan balon udara dengan dunia penerbangan ini sangatlah berpengaruh. Menyadari bahwa Balon Udara merupakan salah satu Tradisi lokal yang mempunyai nilai historis dan budaya, pemerintah tidak dapat menghilangkan tradisi ini secara sepenuhnya dalam festival mengenai balon udara di Wonosobo. Namun pemerintah juga harus membuat kebijakan bahwa penerbangan balon udara tetap boleh dilakukan dengan ketentuan harus diikat agar tidak dapat terbang bebas dan mengganggu jalur pernerbangan pesawat yang dapat berdampak membahayakan keselamatan penerbangan. Sehingga, dalam hal ini peneliti menentukan 2 (dua) rumusan masalah sebagai berikut: (1) mengapa penerbangan balon udara dianggap membahayakan bagi dunia penerbangan; (2) bagaimana pelaksanaan sanksi bagi penerbang balon udara illegal tersebut.

Dalam penelitian ini menggunakan refrensi penelitian sebelumnya yang dilakukan oleh beberapa peneliti yang membahas mengenai keselamatan dalam dunia penerbangan. Hasil penelitian sebelumnya akan digunakan untuk mendukung hasil penelitian ini. Penelitian dari Finda Luthfiany Ustidivanissa, Rinitami Njatrijani, dan Agus Pramono mengenai Tinjauan Yuridis Pengoperasian Pesawat Tanpa Awak Terhadap Keselamatan Penerbangan di Wilayah Negara Kesatuan Republik Indonesia (Studi Pada PT. Uavindo Nusantara, Bandung). Dalam permasalahan ini sama saja seperti permasalahan penerbangan pesawat tanpa awak atau yang sering kita sebut dengan drone, tetapi perbedaannya drone sendiri memiliki remote untuk mengendalikan penerbangannya, beda dengan balon udara yang 
Jurnal Pembangunan Hukum Indonesia

Volume 2, Nomor 2, Tahun 2020
Program Studi Magister IImu Hukum Fakultas Hukum Universitas Diponegoro hanya dilepas ketika diterbangkan, walaupun sonar pesawat menangkap dua objek tersebut, tetapi kemungkinannya terjadi potensi kecelakaan cukup kecil untuk drone, beda dengan balon udara yang ketika sudah diterbangkan susah untuk diawasi (Ustidivanissa, Njatrijani, \& Pramono, 2017).

Dalam penelitian Tanod Witny mengenai Analisis Yuridis terhadap Penggunaan Kekuatan Bersenjata dengan Menggunakan Pesawat Tanpa Awak (Unmanned Drones). Penelitian ini sama hal nya dengan penelitian tentang pengoperasian pesawat tanpa awak sebelumnya. Penulis dalam penulisan ini terfokus pada pengoperasian penggunaan alat pada pesawat tanpa awak (Witny, 2013).

Penelitian yang dilakukan oleh Alfredo Pasaribu dan Achmad Solichin ini berfokus pada penerapan knowledge management system yang dapat menambah pengetahuan personil dan diharapkan dapat mengurangi kecelakaan akibat human error. Penulis dalam hal ini akan menjelaskan juga mengenai akibat dalam kecelakaan pesawat yang diakibatkan pada human error (Pasaribu, \& Solichin, 2017).

Penelitian yang dilakukan oleh Arief Yulianto ini berfokus pada peningkatan kualitas dalam pelayanan penerbangan setelah terjadinya insiden kecelakaan. Dalam hal ini penulis akan berfokus pada tingkat kualitas dalam pelayanan keselamatan penerbangan (Yulianto, 2010).

Penelitian yang dilakukan oleh Wahdah Zainal Imam ini berfokus pada tanggung jawab pemerintah dalam membuat kewenangan dalam pengaturan penerbangan, sehingga penulis dalam menggunakan refrensi penelitian sebelumnya ini akan menguraikan mengenai bagaimana kebijakan yang dibuat oleh pemerintah dalam pengaturan penerbangan (Imam, 2020).

\section{B. METODE PENELITIAN}

Metode penelitian yang peneliti gunakan ini adalah tipe penelitian yuridis normatif (format penelitian doktrinal). Pendekatan yuridis normatif yaitu penelitian hukum yang dilakukan dengan cara meneliti bahan pustaka atau data sekunder sebagai bahan dasar untuk diteliti dengan cara mengadakan penelusuran terhadap peraturan-peraturan dan literatur-literatur yang berkaitan dengan permasalahan yang diteliti (Soekanto, \& Mamudji, 2001). Pendekatan yang digunakan yakni pendekatan konseptual (conceptual approach). Spesifikasi yang penulis gunakan yaitu deskriptif analitis dengan mengungkapkan peraturan perundang-undangan yang berkaitan dengan teoriteori hukum yang menjadi objek penelitian. Metode pengumpulan data yang digunakan yaitu melalui 
Jurnal Pembangunan Hukum Indonesia

Volume 2, Nomor 2, Tahun 2020
Program Studi Magister IImu Hukum Fakultas Hukum Universitas Diponegoro penelitian kepustakaan (library research). Sumber data diperoleh dari data sekunder yang terdiri atas bahan hukum primer (Kitab Undang-Undang Hukum Pidana dan lain-lain), bahan hukum sekunder (berbagai buku dan artikel jurnal maupun hasil penelitian) dan bahan hukum tersier (Moleong,2000). Analisis data yang digunakan dalam penelitian ini menggunakan analisis kualitatif, artinya menguraikan data yang diolah secara rinci kedalam bentuk kalimat-kalimat (deskritif).

\section{HASIL DAN PEMBAHASAN}

\section{Bahaya Penerbangan Balon Udara}

Pada dasarnya, balon udara adalah sebuah alat yang mampu terbang dengan kecepatan sangat rendah maupun mengambang di udara dengan perubahan ketinggian yang kecil. Dengan perkembangan teknologi robotik dalam bidang penerbangan, penggunaan balon udara juga semakin berkembang. Saat ini balon udara banyak dipakai sebagai media komersial, selain itu penggunaan balon udara juga banyak digunakan untuk memonitoring cuaca dengan menerbangkan balon pada ketinggian sekitar 18-37 km. Pengembangan balon udara sebagai pesawat tanpa awak banyak dilakukan pada bidang transportasi untuk kargo, monitoring lingkungan, monitoring trafik kendaraan dan juga pada bidang telekomunikasi (Skuza, Park, Kim, \& Seaman, 2014).

Peggunaan balon udara ini untuk memonitoring trafik ataupun lingkungan, dengan penggunaan sistem posisi dan penjejak menjadi komponen utama dalam sistem kontrol dan sistem navigasi balon udara. Sistem yang paling banyak dipakai saat ini merupakan sistem sederhana yang mengandalkan bantuan global positioning satellite (GPS) dengan titik lintang dan bujur yang sudah didefinisikan dan sistem kontrol PID untuk mengatur ketinggian dan arah tujuan balon udara saat ini (Ramos, et al, 2001). Namun nyatanya hanya dengan menggunakan GPS pada sistem navigasi pada balon udara saja masih sangat kurang, diikarenakan dalam penyimpangan yang terjadi masih sangat besar dengan orde meter (Yang, Wu, \& Zheng, 2012).

Penerbangan balon udara sudah menjadi tradisi di Kabupaten Wonosobo, dimana masyarakat berlomba-lomba untuk membuat balon dengan bentuk yang sangat variatif. Lomba balon udara ini dilaksanakan pada saat setelah hari raya iedul fitri, dan tradisi penerbangan balon udara ini sebagai salah satu daya tarik wisata di Kabupaten Wonosobo. Karena menjadi daya tarik wisata, penerbangan balon udara dijadikan sebagai adu 
Jurnal Pembangunan Hukum Indonesia

Volume 2, Nomor 2, Tahun 2020
Program Studi Magister IImu Hukum Fakultas Hukum Universitas Diponegoro bergengsi antar peserta penerbang balon udara, peserta yang mengikuti lomba penerbangan balon udara ini biasanya terdiri atas beberapa grup dari setiap desa di Kabupaten Wonosobo dan perseorangan.

Penerbangan balon udara dianggap sangat membahayakan bagi dunia penerbangan oleh Pemerintah karena dapat mengganggu lalu lintas penerbangan dan membahayakan penumpang pesawat. Penerbangan balon udara ini dapat membahayakan pesawat jika sampai material balon tersangkut ke baling-baling atau bagian pesawat lainnya. Selain dapat membahayakan dalam dunia penerbangan, fenomena pelepasan balon udara ini juga dapat mengancam citra Indonesia di mata Internasional dan akan berbahaya jika masuk sampai ke jalur internasional seperti Negara Bangkok, Brisbane, Melbourne, dan sebagainya, sehingga Negara bisa dikenakan penalty untuk tidak bisa melakukan penerbangan ke wilayah Internasional.

Salah satu tujuan diselenggarakannya penerbangan adalah untuk mewujudkan penyelenggaraan penerbangan yang aman (Safety), tertib dan teratur (regularity), nyaman (comfotable), dan ekonomis (economy for company). Praktek dalam kegiatan transportasi udara niaga sering kali pengangkut tidak memenuhi kewajibannya secara baik dan benar atau dapat dikatakan telah melakukan wanprestasi. Beberapa kasus atau fakta yang dapat dikat egorikan sebagai bentuk wanprestasi oleh pengangkut adalah tidak memberikan keselamatan, kenyamanan dan keamanan penerbangan kepada penumpang (Nuraini, 2017).

Tingkat kecelakaan pada penerbangan semakin meningkat dari tahun ke tahun. Hal ini sangat disayangkan mengingat kebutuhan masyarakat Indonesia terhadap transportasi udara pun semakin meningkat. Untuk melakukan pencegahan atau antisipasi terhadap kemungkinan kecelakaan penerbangan perlu diketahui terlebih dahulu aspek budaya dari penyebab-penyebab utama dari kecelakaan penerbangan. Sebuah kecelakaan penerbangan dapat disebabkan oleh beberapa faktor dan melibatkan berbagai pihak (Sutalaksana, \& Sandika, 2018).

Namun dalam faktanya, penyebab dalam kecelakaan pesawat terbang tersebut tidak karena faktor penerbangan balon udara. Penyelenggaraan industri penerbangan nasional beberapa tahun belakangan ini masih menimbulkan permasalahan. Salah satunya adalah sering terjadinya rangkaian kecelakaan pesawat udara dengan beragam sebab, sehingga menimbulkan kerugian terhadap penumpang sebagai konsumen. Beragam faktor penyebab terjadinya kecelakaan pesawat udara dapat disebabkan oleh berbagai faktor. Mulai dari 
Jurnal Pembangunan Hukum Indonesia

Volume 2, Nomor 2, Tahun 2020
Program Studi Magister IImu Hukum Fakultas Hukum Universitas Diponegoro faktor kesalahan manusia (human error), masalah pada mesin pesawat udara (machine / technical) hingga faktor cuaca (weather). Beberapa ahli di bidang penerbangan juga menemukan fakta bahwa semakin canggih teknologi peralatan penerbangan untuk mengurangi atau meminimalisir situasi spesifik tertentu, seperti alat mendeteksi pesawat udara yang semakin mendekat atau teknologi pendaratan otomatis, maka semakin besar pula kemungkinan kapten penerbangan mengalami kesalahan atau kelalaian (Puspandari, 2017).

Dalam Kongres Amerika Serikat menugaskan FAA untuk memastikan derajat keselamatan yang paling tinggi dalam penerbangan (to assure the highest degree of safety in flight). FAA bertanggung jawab memberikan nasihat, bimbingan, dan pengawasan (advice, guidance, oversight) dalam bidang keselamatan kepada industri penerbangan. Ada tiga unsur yang memberikan kontribusi pada keselamatan penerbangan. Pertama, pesawat terbangnya sendiri, bagaimana pesawat itu didesain, dibuat, dan dirawat; Kedua, sistem penerbangan negara, airport, jalur lalu lintas udara, dan air traffic controls; Ketiga, airlines flight operations yang berkaitan dengan pengendalian dan pengoperasian pesawat (Sudiarto, 2012).

Kecelakaan penerbangan di Indonesia yang masuk kelompok serius insiden lebih tinggi daripada kelompok accident. Hal ini merupakan masalah yang cukup rumit. Mekanisme penyelidikan yang dilakukan KNKT dengan menggunakan pedoman berdasarkan pada Peraturan Nasional dan Internasional yang konsisten. Tujuan tunggal dalam penyelenggaraan penyelidikan kecelakaan oleh KNKT adalah mencari setiap penyebab yang berpengaruh terhadap terjadinya kecelakaan. Selanjutnya hasil dari penyelidikan ini dapat dipergunakan untuk meningkatkan kondisi dan tindakan keselamatan penerbangan guna mencegah kecelakaan dengan penyebab yang sama dikemudian hari. Berdasarkan uraian tersebut maka rekomendasi yang diberikan KNKT adalah tidak komprehensif, hanya berdasarkan atas dasar tiap kejadian, padahal kecelakaan pesawat terbang yang paling penting adalah dengan mengungkap kondisi "Latent/tersembunyi" yang harus diungkap, maka analisis yang komprehensif diperlukan untuk mengamati akar permasalahan yang paling dalam (Poerwanto, \& Mauidzoh, 2016).

Menyadari pentingnya peranan transportasi udara tersebut dalam pertumbuhan daerah dan pengembangan wilayah serta dalam kehidupan manusia di seluruh dunia, International Civil Aviation Organization (ICAO) mengadakan Konvensi Internasional yang mengatur tentang Penerbangan Sipil dan telah mengikat 190 negara yaitu Convention on International Civil Aviation atau sering dikenal 
Jurnal Pembangunan Hukum Indonesia

Volume 2, Nomor 2, Tahun 2020
Program Studi Magister IImu Hukum Fakultas Hukum Universitas Diponegoro dengan Konvensi Chicago 1944. Indonesia sebagai salah satu Negara anggota dari Konvensi tersebut, mengeluarkan regulasi terhadap kegiatan penerbangan, yaitu Undang-Undang No. 1 Tahun 2009 tentang Penerbangan, dimana menurut Pasal 1 angka 1 Undang-Undang No.1 Tahun 2009 tentang Penerbangan menyebutkan bahwa Penerbangan adalah satu kesatuan sistem yang terdiri atas pemanfaatan wilayah udara, pesawat udara, bandar udara, angkutan udara, navigasi penerbangan, keselamatan dan keamanan, lingkungan hidup, serta fasilitas penunjang dan fasilitas umum lainnya (Pasal 1 Angka 1 Undang-Undang No. 1 Tahun 2009 tentang Penerbangan).

\section{Penerapan Sanksi Penerbang Balon Udara llegal}

Guna untuk dapat menyelenggarakan pemerintahan, administrasi negara mempunyai beberapa keleluasaan demi terselenggaranya kesejahteraan masyarakat tanpa meninggalkan asas legalitas. Hal ini berarti bahwa sikap tindak administrasi negara tersebut haruslah dapat dipertanggungjawabkan, baik secara moral maupun secara hukum. Lord Acton, mengatakan bahwa setiap kekuasaan sekecil apapun cenderung untuk disalahgunakan. Oleh sebab itu, dengan adanya keleluasaan bertindak dari administrasi negara yang memasuki semua sektor kehidupan masyarakat, kadang-kadang dapat menimbulkan kerugian bagi masyarakat itu sendiri. Maka, wajarlah bila diadakan pengawasan terhadap jalannya pemerintahan, yang merupakan jaminan agar jangan sampai keadaan negara menjurus kea rah dictator tanda batas, yang berarti bertenangan dengan asas negara hukum (Koentjoro, 2004).

Sebagai upaya untuk membangun stakeholders dalam kegiatan penerbangan yang memiliki budaya patuh terhadap aturan-aturan hukum yang terkait dalam kegiatan penerbangan ialah dengan menciptakan kesadaran hukum (rechtsbewustijn) bagi para stakeholdes kegiatan penerbangan tersebut. Kesadaran untuk mematuhi aturan hukum tersebut tentunya dapat terlaksana dengan baik apabila para stakeholders dalam kegiatan penerbangan tersebut memiliki budaya hukum yang tinggi untuk mematuhi segala peraturan yang terkait dengan upaya pelaksanaan keselamatan penerbangan. Sebab apabila budaya untuk mematuhi dan melaksanakan hukum tersebut berjalan dengan baik, maka kejadian kecelakaan penerbangan tersebut dapat diminimalisir (Purba, 2017).

Budaya Keselamatan merupakan suatu hal yang diperoleh melalui proses kombinasi antara Budaya Organisasi, Budaya Profesional dan juga dari Budaya Nasional. Salah satu upaya untuk 
Jurnal Pembangunan Hukum Indonesia

Volume 2, Nomor 2, Tahun 2020

mengimplementasikan budaya dalam keselamatan penerbangan tersebut ialah dengan memperkenalkan budaya tersebut kepada para stakeholders dalam kegiatan pnerbangan, dengan memberikan edukasi berupa pendidikan dan pelatihan (intoduces the culture during training season), dimana seluruh pekerja instansi-instansi yang bergerak dalam kegiatan penerbangan diberikan pelatihan tersebut agar memiliki pengetahuan dalam melaksanakan safety culture tersebut, agar nantinya dapat memahami dan mengetahui dengan baik apa itu budaya keselamatan penerbagan dan bagaimana cara untuk melaksanakannya. Dimana dengan memberikan pemahaman yang baik bagi para stakeholders dalam kegiatan penerbangan tersebut dengan baik melalui proses pendidikan dan pelatihan, safety culture dapat berjalan dengan baik (Fikarno, 2009).

Menurut Undang-Undang Nomor 1 Tahun 2009 tentang Penerbangan, dalam Pasal 10 ayat (1) dikatakan bahwa, "Penerbangan dikuasai oleh negara dan pembinaannya dilakukan oleh pemerintah." Sedangkan pada Pasal 10 ayat (2), disebutkan, "Pembinaan penerbangan sebagaimana dimaksud pada ayat (1) meliputi aspek pengaturan, pengendalian dan pengawasan" (UU NO.1 TAHUN 2009).
Program Studi Magister Ilmu Hukum Fakultas Hukum Universitas Diponegoro
Pemerintah Kabupaten Wonosobo juga telah
bekerja sama dengan Kepolisian Resor Kabupaten Wonosobo untuk menertibkan penerbangan balon udara melalui razia secara rutin pada saat hari besar untuk mengantisipasi terjadinya penerbangan balon udara yang terbang secara ilegal tanpa izin yang mana ini dianggap dapat membahayakan keselamatan penerbangan pesawat. Karena biasanya penerbang ilegal ini melakukan penerbangan balon udara tersebut dianggap melebihi batas tinggi yang sudah ditentukan, balon-balon ilegal tersebut terbang pada jalur pesawat melintas. Hal ini bisa berdampak buruk terhadap jalur penerbangan, pasalnya jika balon udara mengenai mesin pesawat dapat mengakibatkan kerusakan parah pada mesin dan berakibat jatuhnya pesawat. Namun pada faktanya selama ini belum pernah terjadi kecelakaan pesawat yang diakibatkan oleh balon udara, mengingat tradisi balon udara sudah berlangsung lama, sudah menjadi rutinitas dan kebiasaan masyarakat pada setiap moment perayaan hari besar.

Berdasarkan pada International Investigation Standards Annex 13-Aircraft Accident and Incident Investigation, tenth Edition-July 2010, incorporating Amendment 14 and supplement, Undang-Undang Nomor: 1 Tahun 2009 tentang Penerbangan dan Peraturan Pemerintah Republik Indonesia nomor 62 
Jurnal Pembangunan Hukum Indonesia

Volume 2, Nomor 2, Tahun 2020

Tahun 2013, tentang Investigasi Kecelakaan Transportasi, Pasal 9 menyatakan bahwa Kecelakaan Pesawat Udara dapat terdiri atas: a Pesawat Udara yang jatuh pada saat tinggal landas, lepas landas, atau selama penerbangan; b. tabrakan antar Pesawat Udara atau antar Pesawat Udara dengan fasilitas di bandar udara; c. Pesawat Udara yang hilang atau tidak dapat diketemukan; dan/atau; d. Pesawat Udara yang mengalami Kejadian Serius (serious incident) (Abraham, Spatznick, \& Goldsteran, 2011).

Pemerintah melalui Kementerian Perhubungan juga telah menegaskan mengenai larangan menerbangkan balon udara apalagi yang tidak berizin (ilegal) karena dapat membahayakan keselamatan penerbangan. Larangan ini sudah sesuai dengan Undang-Undang Nomor 1 Tahun 2009 tentang penerbangan, dimana apabila menerbangkan balon udara dapat mengganggu lalu lintas penerbangan dan membahayakan penumpang pesawat. Setiap pelanggar dapat diancam pidana 2 tahun penjara dan denda Rp 500 juta. Selain melanggar UU No.1 Tahun 2009, Indonesia juga dapat terkena sanksi dari Organisasi Penerbangan Sipil Internasional (ICAO) berupa larangan penerbangan internasional.
Program Studi Magister IImu Hukum Fakultas Hukum Universitas Diponegoro

Hasil wawancara peneliti dengan Kepala Kantor Kesatuan Bangsa dan Politik Kabupaten Wonosobo, dalam upaya penertiban dan penindakan pelanggaran penerbangan balon udara di Kabupaten Wonosobo, Pemerintah bekerjasama dengan Kepolisian dan TNI selalu melakukan razia dalam upaya menertibkan sekaligus mensosialisasikan mengenai larangan menerbangkan balon udara secara ilegal. Dalam melakukan penertiban Instansi yang diberikan kewenangan diantaranya adalah Polres dikarenakan dasar hukum yang digunakan adalah Undang-undang No. 1 Tahun 2009, didukung oleh Kesatuan Bangsa dan Politik (KESBANGPOL), dan jajaran Pimpinan Kecamatan, serta Dinas Perhubungan Provinsi Jawa Tengah, serta bekerjasama dengan Airnav Indonesia. Apabila terdapat masyarakat yang terbukti melanggar menerbangkan balon udara secara ilegal, maka akan dikenakan sanksi tegas berupa proses pidana sesuai dengan ketentuan Undang-undang Keselamatan Penerbangan, serta dilakukan penyitaan dan pembinaan bagi masyarakat yang membuat, menyimpan, dan memperjual-belikan balon udara dan sejenisnya tanpa memiliki izin dari Pejabat berwenang.

Sejauh ini sanksi tersebut sudah diterapkan secara tegas bagi siapapun yang terbukti menerbangkan maka akan langsung di proses 
Jurnal Pembangunan Hukum Indonesia

Volume 2, Nomor 2, Tahun 2020

pidana. Namun pada kenyataanya belum ada penelitian terkait dengan daya jelajah balon udara, dan ketinggian jalur penerbangan di langit Wonosobo, apakah benar balon udara mencapai jalur penerbangan yang dapat membahayakan pesawat masih belum dapat dipastikan. Karena dasar hukum yang dipakai adalah Undang-undang No. 1 Tahun 2009 seperti yang dijelaskan pada pasal 210 yang berbunyi "Setiap orang dilarang berada di daerah tertentu di Bandar Udara membuat halangan tertentu, dan atau melakukan kegiatan lain di kawasan keselamatan pada operasi penerbangan yang dapat membahayakan keselamatan penerbangan kecuali memperoleh izin dari otoritas Bandar Udara".

\section{SIMPULAN}

Penerbangan balon udara saat ini sudah menjadi tradisi bagi masyarakat Kabupaten Wonosobo, dimana tradisi ini kemudian menjadi daya tarik wisata bagi para pengunjung. Namun ada pendapat lain yang mengatakan bawa dalam Penerbangan balon udara ini dianggap sangat membahayakan bagi dunia penerbangan oleh Pemerintah karena dapat mengganggu lalu lintas penerbangan dan membahayakan penumpang pesawat. Penerbangan balon udara ini dapat membahayakan pesawat jika sampai ada material
Program Studi Magister Ilmu Hukum Fakultas Hukum Universitas Diponegoro

balon yang tersangkut ke baling-baling atau bagian pesawat lainnya. Selain dapat membahayakan dalam dunia penerbangan, fenomena pelepasan balon udara ini juga dapat mengancam citra Indonesia di mata Internasional dan akan berbahaya jika masuk sampai ke jalur internasional dan Negara akan mendapat penalty.

Sebagai upaya untuk membangun kesadaran hukum terhadap masyarakat Kabupaten Wonosobo, Pemerintah bekerja sama dengan Kementerian Perhubungan, Air-Navigation dan Kepolisian Resor Kab. Wonosobo untuk menertibkan masyarakat yang melakukan penerbangan balon udara secara illegal dikarenakan ini sangat menganggu penerbangan pesawat. Larangan ini sudah sesuai dengan UndangUndang Nomor 1 Tahun 2009 tentang Penerbangan, dimana apabila menerbangkan balon udara secara illegal tanpa izin dari pemerintah setempat akan mendapat ancaman pidana 2 tahun penjara dan denda Rp 500 juta (lima ratus juta rupiah).

\section{DAFTAR PUSTAKA}

\section{BUKU}

Adisasmita. (2014). Analisis Kebutuhan Transportasi. Yogyakarta: Graha Ilmu.

Koentjoro, Diana H. (2004). Hukum Administrasi Negara. Jakarta: Ghalia Indonesia. 
Jurnal Pembangunan Hukum Indonesia

Volume 2, Nomor 2, Tahun 2020

Moleong, Lexy J. (2000). Metode Penelitian Kualitatif.

Bandung: Remaja Rosdakary.

Soerjono, Soekanto., \& Mamudji, Sri. (2006).

Penelitian Hukum Normatif. Jakarta: Raja Grafindo Persada.

\section{J URNAL}

Sudiro, A. (2011). "Product Liability" Dalam Penyelenggaraan Penerbangan. J urnal Hukum dan Pembangunan, Vol. 41, (No.1), pp. 186206.

Abraham, Milkovich, E., Spatznick, A., \& Goldsteran, M. (2011). Effect of High Density Concrete on Design of Shielding Radiation for Industrial Testing. J ournal of Radiation, Vol. 10, (Issue 1), pp. 31-35.

Imam, Wahdah Z. (2020). Konsepsi Tanggung Gugat Pemerintah Dalam Industri Penerbangan. J urnal Amanna Gappa, Vol. 28, (No.1), pp. 111.

Khairandy, R. (2006). Tanggung Jawab Pengangkut dan Asuransi Tanggung Jawab Sebagai Instrumen Perlindungan Konsumen Angkutan Udara. Jurnal Hukum Bisnis, Vol. 25, (No.1), p.21.

Nuraini, S. (2017). Tanggung Jawab Keperdataan Dalam Penyelenggaraan Pengangkutan Udara Atas Keterlambatan Jadwal Penerbangan
Program Studi Magister IImu Hukum Fakultas Hukum Universitas Diponegoro

Berdasarkan Undang-Undang Nomor 1 Tahun 2009 Tentang Penerbangan. Privat Law, Vol. V, (No. 1 Januari-Juni), pp. 62-72.

Pasaribu, Alfredo., \& Solichin, Achmad. (2017). Pengembangan Aplikasi Knowledge Management System Helicopter Landing Officer Pada PT Pacific Aviation Indonesia. Jurnal RESTI (Rekayasa Sistem dan Teknologi Informasi), Vol. 1, (No.3), pp. 232238.

Poerwanto, Eko., \& Mauidzoh, Uyuunul. (2016).

Analisis Kecelakaan Penerbangan Di Indonesia Untuk Peningkatan Keselamatan Penerbangan. J urnal Angkasa, Vol. 8, (No. 2, November), pp. 1-18.

Purba, H. (2017). Mewujudkan Keselamatan Penerbangan Dengan Membangun Kesadaran Hukum Bagi Stakeholders Melalui Penerapan Safety Culture. Jurnal Hukum Samudra Keadilan, Vol.12, (No.1 Januari-Juni), pp. 95110.

Puspandari, Retno. (2017). Tanggung Jawab Perusahaan Jasa Penerbangan terhadap Kecelakaan pada Penumpang Berdasarkan Undang-undang Nomor 1 Tahun 2009 Tentang Penerbangan. J urnal Privat Law, Vol. 5 (No.1), pp. 95-105. 
Jurnal Pembangunan Hukum Indonesia

Volume 2, Nomor 2, Tahun 2020

Saefullah, T. (2003). Status dan Tanggung Jawab

Awak Pesawat Udara Dalam Hukum Nasional Indonesia. Jurnal Ilmu Hukum Madani, Fakultas Hukum Universitas Islam Bandung, Vol.5, (No.3, November), p. 208.

Sudiarto. (2012). Tanggung Gugat Pemerintah Terhadap Kecelakaan Pesawat Udara di Indonesia. Jurnal Amanna Gappa, Vol.20, (No.3), pp. 273-287.

Sutalaksana, Iftikar Z., \& Sandika, Edwina Dwi. (2018). Mengkaji Kelengkapan Human Factors Analysis And Classification System (HFACS) dari Sisi Budaya berdasarkan Dimensi Budaya dari Trompenaars. Jurnal Teknologi Industri, Program Studi Teknik Industri, ITB, Vol.2, (No.2), pp. 5-11.

Ustidivanissa, Finda Luthfiany., Njatrijani, Rinitami., \& Pramono, Agus. (2017). Tinjauan Yuridis Pengoperasian Pesawat Tanpa Awak Terhadap Keselamatan Penerbangan di Wilayah Negara Kesatuan Republik Indonesia (Studi Pada PT. Uavindo Nusantara, Bandung). Diponegoro Law Journal, Vol.6, (No.2), pp.1-13.

Witny, T. (2013). Analisis Yuridis terhadap

Penggunaan Kekuatan Bersenjata dengan

Menggunakan Pesawat Tanpa Awak (Unmanned Drones). Lex Crimen, Vol. 2,
Program Studi Magister IImu Hukum Fakultas Hukum Universitas Diponegoro

(No.1), pp. 110.

Yang, Yu eneng., Wu, Jie., \& Zheng, Wei. (2012). Design, modeling and control for a stratospheric telecommunication platform. Acta Astronautica, Vol. 80, (No. 1 NovemberDecember), pp. 181-189.

Yulianto, A. (2010). Meningkatkah Kualitas Pelayanan Jasa Penerbangan Indonesia Paska Insiden Kecelakaan Pesawat Terbang?. J urnal Dinamika Manajemen, Vol.1, (No.1), pp. 1-8.

\section{SUMBER LAINNYA :}

Aflah., \& Zulfii, Chairi., (2016). Tanggung Jawab Pengelola Bandar Udara Dalam Pelayanan Lalu Lintas Penerbangan Untuk Keamanan dan Keselamatan Penerbangan (Studi Pada Bandar Udara Internasional Hang Nadim). Laporan Hasil Akhir Penelitian, Lembaga Penelitian Universitas Sumatera Utara, Medan.

Fikarno, Dave A. (2009). Faktor-Faktor Penyebab Rendahnya Keselamatan Penerbangan Di Indonesia. Tesis Magister Perencanaan dan Kebijakan Publik, Program Pascasarjana, Fakultas Ekonomi, Universitas Indonesia, Depok.

Skuza, Jonathan R., Park, Yeonjoon., Kim, Hyun Jung., \& Seaman, Shane T. (2014). Feasibility 
Jurnal Pembangunan Hukum Indonesia

Volume 2, Nomor 2, Tahun 2020

study of cargo airship transportation systems powered by new green energy technologies. NASA: Center for AeroSpace Information Retrived from https://ntrs.nasa.gov/archive/ nasa/casi.ntrs.nasa.gov/20140006040.pdf).

Ramos, Joshue Jr G., Paiva, Ely Carneiro de Paivan., \& Azinheira, Jose Raul., Bueno, Samuel Siqueira., Maeta, Silvio Mano., Mirisola, Luis Gistavo Bizzaro., Bergerman, Marcel., \& Faria, Bruno Guedes. (2001). Autonomous flight experiment with a robotic unmanned airship. Seoul, Korea : In IEEE international conference on robotics and automation. $\quad$ Retrieved from http://www.ent.mrt.ac.Ik/iml/paperbase/ICRA_ CDs/ICRA2001/PDFFILES/PAPERS/ICRA_PA PERS/Z0299.pdf).

\section{UNDANG-UNDANG}

Undang - undang Nomor 1 Tahun 2009 Tentang Penerbangan.

Peraturan Menteri Perhubungan Republik Indonesia Nomor 48 Tahun 2018 Tentang Penggunaan Balon Udara Pada Kegiatan Budaya Masyarakat.

Peraturan Daerah nomor 2 tahun 2016 tentang Ketertiban dan Ketentraman masyarakat. ICAO (ICAO) dan Commercial Aviation Safety Team
Program Studi Magister IImu Hukum Fakultas Hukum Universitas Diponegoro

(CAST), Aviation Occrrence Categories, Definitions and Usage Notes, May 2011. 